\title{
The Implementation of Parenting at Elementary School
}

\author{
Halimah Nur Amini \\ Pascasarjana, Institut Agama Islam Negeri Palangka Raya \\ Palangka Raya, Indonesia \\ desi.erawati@iain-palangkaraya.ac.id
}

\author{
Desi Erawati \\ Institut Agama Islam Negeri Palangka Raya \\ Palangka Raya, Indonesia
}

\begin{abstract}
The parents' role to child education becomes the important thing. The school becomes continuing education from home education. In order to grow well for child's education, it is required good parenting patterns as well. Viewing this phenomenon, the school's parenting program becomes a necessary for delivering child's development of their religious, intelligence, psychology, and social. The purpose of this study is to investigate the process of school parenting program. The method used in this study is descriptive qualitative research, with the informants are school principals, teachers (parent executive committee), and students' parents. Data collection is done through interviews, documentation, and field observation. The results of this study reveal that the implementation of parenting is done well. It is evidenced that students' parents increase their insight, parents appreciate what is done by children and school becomes a place for students' parents to learn.
\end{abstract}

\section{Keywords - implementation of parenting; elementary school}

\section{INTRODUCTION}

An integrated Islamic elementary school in Palangka Raya Town, Indonesia, is one of the primary schools implementing parenting programs, where the program is also implemented in several other elementary schools [1]. Based on the interview result with the related education offices, the program is still formal, for example, during meetings with new learners at school or at the time of distributing the final results (report records) [2]. The parenting program is implemented based on the school's vision and mission, in which the school becomes a learning center for both learners and parents [3]. Parenting implementation at school, in which one of its flagship programs is education for both parents and children [4]. The parenting program takes place three to four times a year [5]. Implementation of parenting has been done in some schools. However, it just not becomes a serious program. Therefore, in this study, the researchers investigate deeper on how the implementation of parenting program in integrated Islamic elementary school, what programs are given, whether all can work well together with parenting program offered by the school [6].

Parenting program plans are held in the form of workshops to students' parents, parenting classes, mother and father's seminars, father's camping, year-end performances, and teacher- students' parents meetings at the end of the semester [7]. Parenting activities in SDIT must be followed by father and mother, where there is a form of activity that is only followed by father. There are activities that only followed mother. Besides, there are activities that must be attended by both father and mother [8]. As a strengthening instrument of the school in the form of attendance list between both father and mother is in the form of parents' commitment to the school program. This has been done at the beginning, for example when receiving new candidate learners [9]. The form of parents' commitment is done by signing a statement letter to be attended by parents including parenting activities [10]. This commitment letter, then, becomes the basic for reinforcing the necessity for parents to attend the school activities and one of them is parenting program [11]. From some previous researches, this research investigates deeper on how the implementation of parenting program in integrated Islamic elementary school can be done and run well as expected, considering the number of school programs offered, whether there are obstacles or not when implementing the parenting program.

\section{METHOD}

Descriptive qualitative method became the approach of this research. The location of the study was conducted in one of the Integrated Islamic Primary School (SDIT) in Palangka Raya, Central Kalimantan Indonesia 2017 academic year. The parenting program activity was established in 2012 until now. In the selection of informants, the researcher used purposive sampling technique. The number of informants was six persons, one headmaster, one school teacher (who participated in parenting activities), and four students' parents of two boys and one girl. The characteristics of the informant (school principal) had managerial experience in the school. The teacher, in this case, beside as a teacher, she is also as the parenting program committee. In addition to supporting data, the representation of students' parents who joined directly the program. The data collection techniques was done through structured interview model (in accordance with the issues discussed), especially related to the implementation of parenting programs at school. The data were collected through documentation as supporting data such as recorded on parenting activities, the number of students. The observations of the study were conducted for five months from June to October 2017. The results of the observations were analyzed through daily diaries evaluated each weekend. Furthermore, the next step is to evaluate. The evaluation is focused on how the 
implementation process of parenting program was done in the school.

\section{RESULTS}

The Integrated Islamic elementary school, in terms of management is different from other public elementary schools. The school has a vision of learning anywhere, with anyone. It means that learning anywhere and by whom we obtain scientific insight. Equally, tracking, camping, Qur'an night, study tours and internships become out of school programs making students passionate to learn and discover the meaningfulness of what they learn. Learning is not only occurred in school buildings, since the meaningful lesson are obtained outside the classroom. Outing program. Learning with anyone means learning not only with classroom teachers. However, everyone can be a teacher according to the momentum and needs. The school often calls experts or parents to teach at school [12]. Based on school observations, the parenting programs had been planned at the first meeting on the outcome of the work meeting. This was done before the beginning of the new school year, precisely in 2010-2011. The good wishes of the headmaster and team of the parenting program committee became an ongoing program. As a basis of this program, the school must empower parents to have the desired parenting skills.

The results of interviews with one of the parenting committee teams revealed that the implementation in an integrated Islamic elementary school located in one of Palangka Raya, Central Kalimantan is packed in various forms such as parenting seminars, father parenting, mother parenting, and father's camp. One of the programs provided such as parenting seminar, the participants were all mother and father from students at the school which was done in the beginning, middle or at the end of the semester of the school year, by calling expert presenters according to need. The next program was father parenting and father's camp. The participants are all fathers of the students of the integrated Islamic elementary school. The form of execution was like the father's special tent with parenting material of the child. It was hoped that fathers can cooperate with school in the psychological development of learners. Similarly, the mother parenting program, the participants were the entire mother of the school's female students.

The programs, based on researchers' observations in the first, second and third months, was done periodically. It could be seen that the parenting program carried out in two to four times. The program can be at the beginning of new teachings, mid-semester and at the time of the final report in the school, as shown in Figure 1.

The principal realized that the school as an instrument of providing educational facilities for parents, ask for parents' commitment also to attend the parenting activities. This parents' commitment was poured in the form of approving by making a commitment letter to attend parenting activities. It was conveyed to parents before the child was officially accepted in an integrated Islamic primary school. When parenting programs was not attended as much as $50 \%$ of parenting activities for one year, then at the end of the semester, parents got a direct rebuke from the school. This parenting program had been running well for eight years.

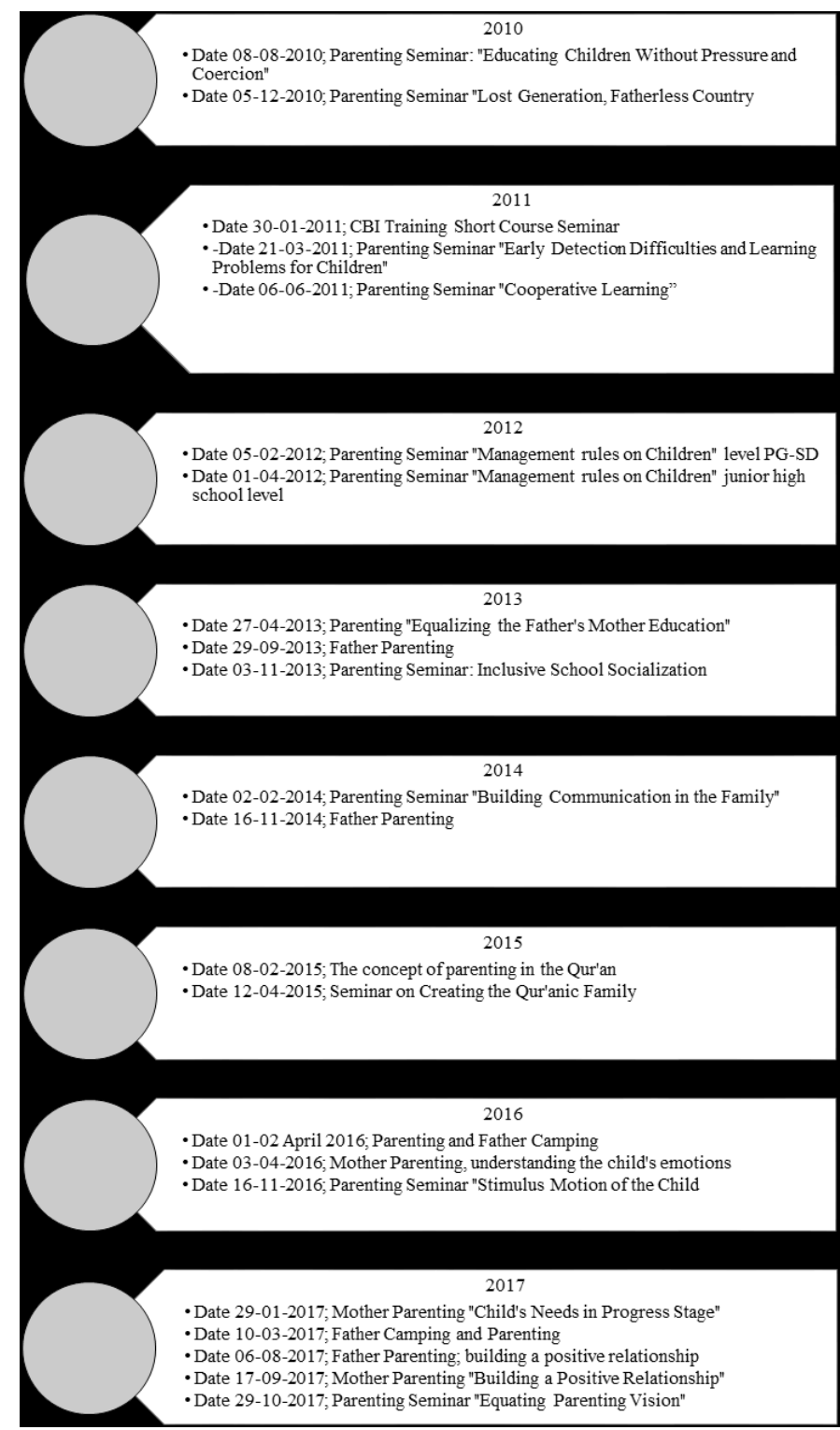

Fig. 1. Parenting Program in Integrated Islamic Primary Sch.

\section{DISCUSSION}

The basis for implementing the parenting program at an integrated Islamic elementary school in one of the first schools in Palangka Raya [13] were as follows. First normative reason (Al-Qur'an, At Tahrim verse 66). [14] Secondly, juridical reason (state policy), in the Law of National Education System number 20 of 2003 article 7, paragraph 2 states, "Parents of the school- age- children are obliged to provide basic education to their children " [15], then the Law of the Republic of Indonesia number 23 of 2002 Article 26 paragraph 1 on the obligations and responsibilities of families and parents on the development and education of their children [16] Next psychological foundations [17] and sociologically reinforce the holding of such programs in public and other schools [18]. A series of 
parenting programs implemented by the school according to the vision and mission of the elementary school [19]. Thus, to determine the program there were three important things that must be emphasized, namely (1) the realization or implementation of a policy [20], (2) occurred in a relatively long time - not a single but continuous plural activity [21], and (3) occurred within an organization involving a group of people [22].

The family according to one of Indonesia's educational figures, Ki Hajar Dewantara in 1935 sparked that families, educational units, and society are the education centers [23]. Good relationships among the three could support the creation of an educational ecosystem fostering the character and culture of achievement [24]. Educational actors and parents at home have a decisive role in establishing a safe learning environment [25], comfortable and fun for children who have an effect on their potential development (2016). Parents and schools were a united whole in educating children. Therefore, what was dreamed by parents or school could be achieved, then there must be consistency from both parties in implementing programs that have been agreed by both parties [26]. One school program prioritizing cooperation between parents and schools was the parenting program [27]. Implementation of the parenting program certainly had a clear vision and mission as well as the readiness of the committee team considering the agenda of this program was half yearly even yearly [28]. It required team committee, budgeting, facilities and infrastructure, and last but not least was the readiness of the school and students' parents [29].

\section{CONCLUSION}

An integrated Islamic elementary school has a school's vision and mission for both students and parents. As a followup, the school prepares a parenting program conducted by the cooperation between the school and students' parents, as evidenced by the form of readiness to follow all activities in the integrated Islamic elementary school. The programs are in the form of workshops both father and mother and camping together.

The obstacles faced are the limited availability of human resources. In this case, the parenting program committee is still minimal since the double role in the school, considering that the programs are quite diverse. Besides, the teacher should be active learning in the classroom. The other obstacles, not all students' parents understand the importance of the program as a follow-up of learning in school then it is continued at home. The frequency of parenting program activities is still quite a few because everything is still on the process stage and always make improvements in the future.

\section{ACKNOWLEDGMENT}

Thank you to the postgraduate director who has given the opportunity to gain academic knowledge and maturity, as well as lecturers who have helped and accompanied this research so that it works well. Further thanks to the integrated Islamic elementary school Sahabat Alam Palangka Raya city, Central Kalimantan, Indonesia, who has provided information both oral and written information may be useful.

\section{REFERENCES}

[1] Crisante, L. (2003). Training in parent consultation skills for primary care practitioners in early intervention in the pre-school context. Australian E-Journal for the Advancement of Mental Health, 2(3), 191200 .

[2] Johnson, B. D., Berdahl, L. D., Horne, M., Richter, E. A., \& Walters, M. (2014). A Parenting Competency Model. Parenting, 14(2), 92-120.

[3] Pazderka, H., Prinz, R. J., Heidebrecht, T., Wiebe, S., Benzies, K. Hosan, N., ... Embry, D. D. (2017). Testing the PAX Good Behavior Game with and without school-based parenting support: study description and practical challenges. International Journal of Mental Health Promotion, 19(4), 173-188.

[4] Widding, U. (2014). Rational and professional, or emotional and 'good enough': Parents negotiating the meaning of parenthood within a parent education programme. Studies in the Education of Adults, 46(1), 42-57.

[5] Guo, M., Morawska, A., \& Filus, A. (2017). Validation of the Parenting and Family Adjustment Scales to Measure Parenting Skills and Family Adjustment in Chinese Parents. Measurement and Evaluation in Counseling and Development, 50(3), 139-154.

[6] Yuen, L. H. (2017). New immigrant parents' experiences in a parent education programme. International Journal of Early Years Education, 0(0), 1-14.

[7] Scott, S., Sylva, K., Beckett, C., Kallitsoglou, A., Doolan, M., \& Ford, T. (2012). Should parenting programmes to improve children's life chances address child behaviour, reading skills, or both? Rationale for the Helping Children Achieve trial. European Journal of Developmental Psychology, 9(1), 47-60.

[8] Ochaita, E., Espinosa, M. A., Garcia-Llorente, I., \& Fernandez-Lopez, M. (2018). The role of NGOs in the dissemination and implementation of positive parenting in Spain. Early Child Development and Care, $0(0)$, $1-14$.

[9] Terlitsky, A. B., \& Wilkins, J. (2015). Characteristics of family literacy programmes that improve child literacy, behaviour and parenting skills. International Journal of Pedagogies and Learning, 10(2), 121-138.

[10] Gerber, S.-J., Sharry, J., \& Streek, A. (2016). Parent training: effectiveness of the Parents Plus Early Years programme in community preschool settings. European Early Childhood Education Research Journal, 24(4), 602-614.

[11] Hopkinson, D. P., \& Johnson, E. J. (2017). Exploring parenting practices of Guyanese parents based on their upbringing: the connections to their children's wayward and wandering behaviors. Early Child Development and Care, 0(0), 1-15.

[12] NH. (2017, February). Interview on the implementation of parenting activity at thje integrated Islamic school.

[13] Yulindrasari, H., \& McGregor, K. (2011). Contemporary Discourses of Motherhood and Fatherhood in Ayahbunda, a Middle-Class Indonesian Parenting Magazine. Marriage \& Family Review, 47(8), 605-624.

[14] RI, D. (1990). Al-Qur"ean and its translation. Jakarta: Departemen Agama.

[15] The Law of National Education System number 20, 2003, U. R. I. N. 2. T. National Education System, Pub. L. No. Article 7, paragraph 3.

[16] The Law of the Republic of Indonesia number 23. 2002, U. R. I. N. 23 , Years. Child Protection, Pub. L. No. Article 26 Paragraph (1).

[17] Fadjukoff, P., Pulkkinen, L., Lyyra, A.-L., \& Kokko, K. (2016). Parental Identity and Its Relation to Parenting and Psychological Functioning in Middle Age. Parenting, 16(2), 87-107.

[18] Merrifield, K. A., Gamble, W. C., \& Yu, J. J. (2015). Using social cognitive theory to understand meta-parenting in parents of young children. Family Science, 6(1), 362-369.

[19] Hastings, S. R., \& Ludlow, T. R. (2006). P5 - A Participatory Program Promoting Pleasurable Parenting: Preliminary Evidence for a Community-Based Parenting Program. Journal of Family Studies, 12(2), 223-245.

[20] Hindman, E., Brooks, A., \& Zwan, R. V. D. (2012). Parenting program uptake: Impacts of implementation factors on intention to enrol. Advances in Mental Health, 10(2), 127-137. 
[21] Rodrigo, Maria Jose, Almeida, A., Spiel, C., \& Koops, W. (2012). Introduction: Evidence-based parent education programmes to promote positive parenting. European Journal of Developmental Psychology, 9(1), 2-10.

[22] Safrudin, S. A. and C. (2009). Evaluation on Education Program (second edition). Jakarta: Bumi Aksara.

[23] Lehmann, J. (2018). Parental involvement: an issue for Swiss primary school teacher education. Journal of Education for Teaching, 44(3), 296-308.

[24] Tan, C., \& Ibrahim, A. (2017). Humanism, Islamic Education, and Confucian Education. Religious Education, 112(4), 394-406.

[25] Zellman, G. L., Perlman, M., \& Karam, R. (2014). How Moroccan mothers and fathers view child development and their role in their children's education. International Journal of Early Years Education, 22(2), 197-209.
[26] Gomez, J. A., Carter, A. S., Forbes, D., \& Gray, S. A. O. (2018). Parental insightfulness and parenting behavior: a two-dimensional analysis of parent contributions to child cognitive outcomes. Attachment \& Human Development, 20(3), 255-271.

[27] Ren, L., \& Edwards, C. P. (2015). Pathways of influence: Chinese parents' expectations, parenting styles, and child social competence. Early Child Development and Care, 185(4), 614-630.

[28] McDonald, L., FitzRoy, S., Fuchs, I., Fooken, I., \& Klasen, H. (2012). Strategies for high retention rates of low-income families in FAST (Families and Schools Together): An evidence-based parenting programme in the USA, UK, Holland and Germany. European Journal of Developmental Psychology, 9(1), 75-88.

[29] Dean, C., Myors, K., \& Evans, E. (2003). Community-wide implementation of a parenting program: the South East Sydney Positive Parenting Project. Australian E-Journal for the Advancement of Mental Health, 2(3), 179-190. 